\title{
Upcoming Workshops
}

\section{Marine Research Drilling in the Atlantic (Magellan WS Series)}

\section{EC $\rightarrow$ RD \\ 2008, Montpellier Ocean Research Drilling \\ 10-12 September \\ France}

Participation on invitation only. Conveners: Marguerite Godard (Université Montpellier 2), Gretchen Früh-Green (ETH Zurich), and Christopher MacLeod (Cardiff University). Contact: Dr. C. J. MacLeod, e-mail: macleod@cardiff.ac.uk

\section{Ultra-High Resolution Geological Records of Past Climate Change}

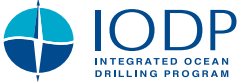

icdp I

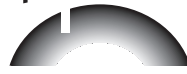

29 Sept.-1 Oct. 2008 , Potsdam, Germany

See details at: http: //www.iodp.org/climatews-workshop/

\section{Scientific Drilling of Sediment in} Lake Ohrid (SCOPSCO)

\section{icdp}

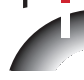

13-17 October 2008, Ohrid, Republic of

Macedonia

Scientific collaboration on past speciation conditions in Lake Ohrid (SCOPSCO) Republic of Macedonia, will be discussed to prepare drilling of sediments in the oldest lake in Europe. See details at: http://ohrid. icdp-online.org

\section{Arctic Ocean History Workshop}

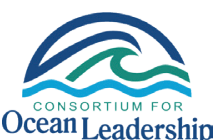

3-5 November 2008,

Bremerhaven, Germany Application Deadline: 24 August 2008

To participate in this workshop, details are given at: www.oceanleadership.org/arctic.
Partial travel support is available. Please contact Bernard Coakley (bernard.coakley@gi.alaska.edu) or Ruediger Stein (rstein@awi-bremerhaven.de) for further information.

\section{Scientific Drilling for Human Origins}

icdp

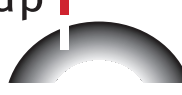

17-21 November 2008, Addis Ababa, Ethiopia

Following recent, successful lake drilling projects in Africa with implications for human origins, the time is right to consider new targets for drilling. A highly promising approach to this goal is to target lacustrine sedimentary sequences currently exposed on-land, in sedimentary basins of world-class importance to hominin evolutionary history. See details at: http:// www.magadi.icdp-online.org 